\title{
Educators Across The Globe Collaborate And Exchange Ideas
}

Usha Rajdev, Marymount University, USA

\begin{abstract}
The Center for Global Education at Marymount University offered unparalleled academic, experiential, and cultural exposure to 17 Marymount University graduate students and two professors who participated in a servicelearning project in Porbandar, India, on January 1-18, 2010. The program focused on teaching PreK-7 grades through an integrated approach. The purpose was to help students in math and science methodology to further their understanding of how a diverse population with little concept of U.S. teaching methods approaches learning mathematics and science concepts. This project aligns with NCATE's Professional Standards in that "American society is becoming more diverse, with students in classrooms drawn from many cultures and ethnic groups. Preparing teachers to teach all students to meet society's demands for high performance has created a new agenda for educators and policymakers." A model was developed with the NCATE's redesign in mind: to transform America's P-12 education system to support higher levels of student learning and success across the spectrum of diverse learners. The goal of this project was to establish a long-term collaborative program between Marymount University School of Education and Human Resources in Arlington, Virginia, and Dr. Virambhai Rajabhai Godhaniya College, in Porbandar, Gujarat, India. As George Bernard Shaw said and Robert Kennedy famously repeated, "Some look at things and ask why. I dream things that never were and ask why not." During a visit to London, England, I was fortunate to meet Dr. Virambhai Godhaniya (for whom the school is named). We seemed to have a common vision of expanding the P-12 education in his Porbandar School to support higher levels of student learning while engaging Marymount University students in learning the value of diversity and education of the whole person. This need for teachers in a successful global society to be broadly educated culturally and academically was demonstrated by Ed Greene, of Montclair State University, in the Harvard Family Research Project (2010). According to Greene, teacher preparation programs should institute lifelong learning principles that encourage students to examine their values, attitudes, standards of acceptable behavior, and the ways in which these influence their beliefs about teaching and learning. What he described is not a one-semester class or a single lecture on culturally diverse families but instead lifelong work that will increase the number of educators who are socially and culturally conscious, competent, and confident as they serve children and families. This concern is echoed by Sherick Hughes, of the University of Toledo, in the same publication, who argues that "teachers need support, motivation, and experiences related to cultures other than their own in order to engage in effective cross-cultural teaching." As an associate professor and a woman of diverse background, I not only value respect for diversity but also model it to my pre-service teachers so that they may implement it in their own classrooms. Marymount University's mission statement refers to "a student-centered learning community that values diversity and focuses on the education of the whole person." Working with students and colleagues abroad enhanced my students' understanding of effectiveness within the multicultural educational system in the United States and fulfilled NCATE's Professional Standard 4 on diversity: "Experiences provided for candidates include working with diverse populations, including higher education and P-12 school faculty, candidates, and students in P-12 schools." In Porbandar, the host schools conducted their teaching through a traditional approach. Rote learning reinforced with blackboard and chalk and paper and pencil appeared to be the main focus of teaching. Children remained at their desks while teachers imparted knowledge through a lecture. There were no indications of inclusion of different learning styles. All students were taught the same material at the same pace. Marymount students did not observe adaptations for diverse learners. Yet it was important for them to understand the culture and the circumstances behind the Indian style of teaching.
\end{abstract}

Keywords: Global Exchange of Methodology 


\section{BACKGROUND}

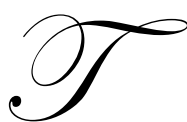
Porbandar, a seaport on the Arabian Sea with a population around 133,083, is the birthplace of Mahatma Gandhi. Eleven percent of the city's total population consists of children younger than six. There is one main street for shopping and beautiful historical buildings throughout the town.

In 2007 - 2008 the number of children in private primary schools in Porbandar was just under 28,000. There are no municipal or municipal-affiliated (public) schools. The table indicates the number of students and teachers and the literacy rate in Porbandar in 2002/2003 (Education Department of Gujarat).

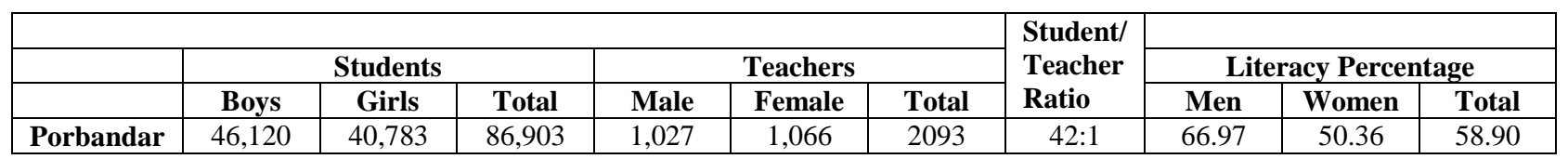

A nonprofit educational institution affiliated with Saurashtra University and recognized by the National Council of Teachers Education (NCTE), Gujarat, Dr. Virambhai Rajabhai Godhaniya College was founded in 1988 through a trust foundation. The B.Ed. program is offered in English, as are other core subjects such as math and science. The college has an open enrollment policy and has approximately 3,000 students. The primary school, Smt. Jayshreeben Virambhai Godhaniya English Medium School, for PreK $-7^{\text {th }}$ grade is on the same grounds as the college. The earliest age of attendance for students is $2 \frac{1}{2}$ years old. The tuition ranges from 4,080 to 4,110 Indian rupees (Rs.) per year (approximately \$90-92) for the primary school students to Rs. 30,000 per year (approximately \$667) for the B.Ed. students (Dr. Virambhai Rajabhai Godhaniya College).

\section{PROJECT GOALS}

The importance of having trained teachers educate the young became apparent through discussions with Porbandar residents, teachers, and school officials. Schools that have the English Medium title had elected to teach in English as per licensure requirements, but despite this title, the teaching was conducted through limited English or no English at all. Most of the instruction in the English Medium School where we taught followed a traditional approach. Blackboards and chalk, and paper and pencil, were the main instructional materials (as seen in the pictures below). The focus was on teaching to the state and national tests at all costs-despite the Gujarat Education Department's requirement that students should be taught through a more purposeful and relevant education with real life experiences using project based learning (PBL). Gujarat Council of Educational Research and Training (GCERT) for Elementary Education implemented this style of teaching in order to reduce rote learning through the application of the PBL methodology. These GCERT goals were to be achieved through doing the hands-on projects, PBL.

\section{THE ENVIRONMENT}

One of the schools we visited had concrete or tiled flooring and bare walls. Children wore uniforms and were required to behave according to high cultural standards of discipline. Children were separated by gender and had to line up with a finger on their lips to maintain silence as they moved through the hallways. 


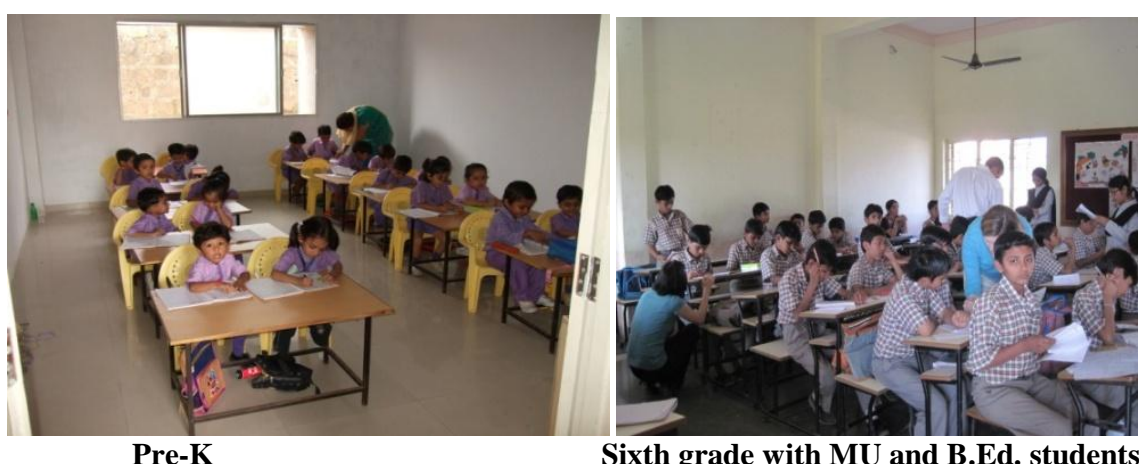

\section{KEY PERSONNEL}

An associate professor of math and science education fluent in both Gujarati and Hindi, I implemented differentiated learning styles to meet the needs of all involved in the program. I wanted Marymount students to develop skills of scientific inquiry and to further their understanding of how a diverse population with little concept of U.S. teaching methods approaches learning core mathematics and science concepts. Diversity is defined by NCATE (2008) as "differences among groups of people and individuals based on ethnicity, race, socioeconomic status, gender, exceptionalities, language, religion, sexual orientation, and geographical area." Keeping this definition in mind, my students would consider how children in India acquired the math and science concepts and then would incorporate this knowledge of a culturally diverse population in their own teaching practices in the United States. The original plan was to take pre-service teachers for ten days and have them teach math and science to the children from PreK-7 using a constructivist approach.

However, plans soon changed as the head of the college wanted to include the B.Ed. pre-service teachers in the methodology training of visiting Marymount students. Then the primary school principal wanted her teachers to learn a hands-on approach. The program soon grew to three times its original size. With the NCATE's "Need for Change" in mind, I designed the model by considering the following steps: preparation prior to leaving, candidates' (pre-service teachers) involvement in Porbandar to gain experiences by working with diverse populations, the host school faculty and higher education (B.Ed.) preparation, and teaching students (children) in PK-7 Indian standards.

\section{PREPARATION}

The Center for Global Education at Marymount University arranged for me to visit the school in Porbandar, India, and plan out the curriculum and the teaching and learning framework during the two weeks visit in July 2009. Upon my return, recruiting began in the fall 2009 classes with PowerPoint presentations and pictures of an envisioned program. Within 24 hours ten students had signed up knowing full well the intensity at which the teaching and learning would occur. Over the course of the week we had seven more students signed up than originally planned to take, ten students. After students completed the application forms, the director of the Center for Global Education at Marymount University began briefing students about the necessary paper work for travel: visas, health information, and passports. Several informational meetings were held thereafter to better prepare the students for international travel since some were travelling for the first time out of the United States. They also needed to prepare for a complete ESL immersion program with a limited English proficient population. They were going to a dry state with a predominantly vegetarian diet. They had to be ready for a potentially life-changing two-week stay.

Prior to departure in fall 2009, pre-service teachers elected either to continue their regular math and science methodology classes or to opt out of them to join the study abroad program in January, with both methodology classes being taught in the United States and in Porbandar. The tuition for Marymount University was the same, but students travelling to Porbandar incurred additional costs to offset their travel, board, and lodging expenses.

The study abroad group met several times for preparation work: classroom assignments, concepts to be taught as required by our counterparts, lists of materials and textbooks needed, and NASA training. With Rick 
Varner, an aerospace education specialist from NASA's Goddard Space Center, students spent a Saturday in activities related to Earth and space, such as measuring distances of the planets from the sun, understanding phases of the moon, calculating the effect of sun rays on UV beads, and making sundials. The students also met with me to gain mathematical conceptual and procedural skills. I presented case studies requiring students to analyze errors and/or misconceptions in mathematics. Using theory and practice, students developed four hands-on strategies to help a student overcome the difficulties encountered. This proved to be good preparation for teaching in Porbandar.

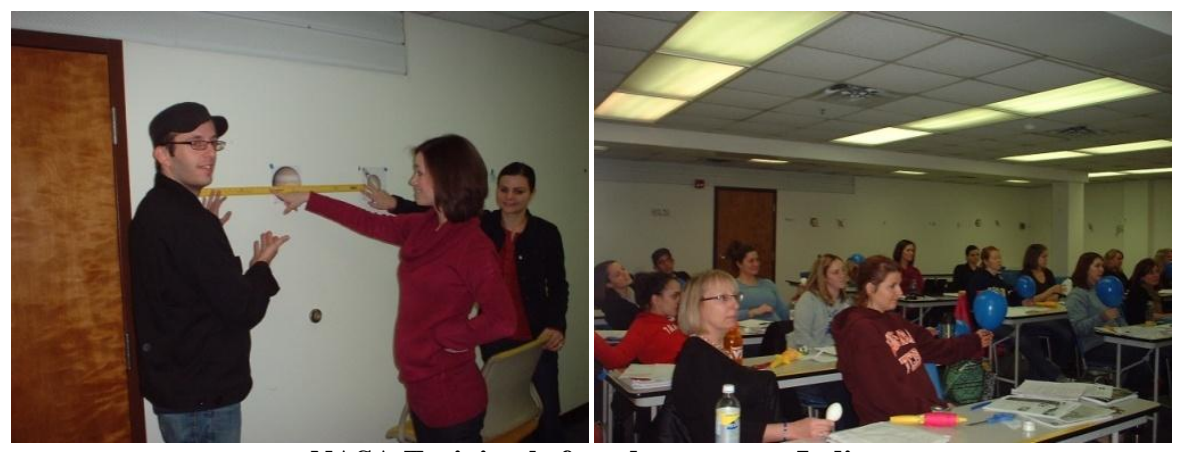

NASA Training before departure to India

Students were also required to complete a two-week integrated unit grid with objectives, titles for each week, activities in math, science, language arts, and two other core subjects from technology, music, art, or social studies. They had to find children's literature related to the content being taught and conduct research to strengthen their own subject knowledge. Their lesson planning included a three-part lesson with the before, during, and after section of the teaching. All lesson plans required extension and accommodation activities to meet the needs of diverse learners. Pre-service teachers also prepared rubrics referencing their objectives for the informal evaluation of students. Students were given Projects WILD and Aquatics and Learning Tree books to help them with the teaching process. As a facilitator for Projects WILD and Learning Tree, I planned to train them for certification in Porbandar.

\section{TEACHING AND LEARNING IN PORBANDAR}

On January 1, 2010, 17 graduate students, Kristie Johnson, and I set out for Porbandar to teach math and science through an integrated constructivist approach. We arrived in Porbandar four days later. We immediately visited Dr. Virambhai Rajabhai Godhaniya College to check the candidates' classrooms and meet their mentor teachers.

For the next ten days, Marymount students worked relentlessly teaching, learning, and understanding the cultural aspects of the population they were immersed in. Every Monday through Friday, for two weeks, they loaded a yellow school bus and were ready to receive and impart academic and cultural knowledge. Wheeling travel bags full of teaching materials in and out of the bus; they were determined to put their numerous hours of preparing and planning to work. The bus dropped them off at the primary-school courtyard, where the principal, B.Ed. students, and their director eagerly awaited their guests.

Initially, the Indian teachers and children were unsure of our American materials and activities, but soon they put the pieces together, and then the excitement in learning began. Although Marymount students and teachers taught all primary-level concepts in both math and science through an integrated approach set by the school and me, the principal had reservations about whether we could cover enough of the Indian curriculum standards of learning through this new methodology for her students to be able to take the required test. The teachers and the principal of the school approached me on the first day asking when these students would be teaching math and language arts. I demonstrated how the integrated approach worked, using children's literature to connect reading, listening, and communication skills with math, social studies, music, art, technology, and science. I also explained how this learning is interwoven into the concept being taught. They seemed cautiously optimistic. 
Marymount students conducted hands-on activities and used visual demonstrations to drive concepts to the level of understanding. To learn about Earth and space, children cut and colored planets (art), measured distances and planet positions (math and social studies), and read children's literature and trade books (language arts). Due to limitations in technology, my pre-service teachers had children visualize the size of a whale by joining hands outside in the courtyard; this was a Project WILD activity. Using an integrated approach, students cut pictures of various marine animals and scaled them to measurable lengths using ratios and proportions (art and math), read books on ocean and marine animals (language arts), and sang songs related to whales (music and movement). Earlier grades learned of Project Learning Tree in a similar manner and used music (Billy B songs became popular) as a focus of teaching and learning. This teaching style implemented learning through Gardner's multiple intelligences (Gardner, 1983).

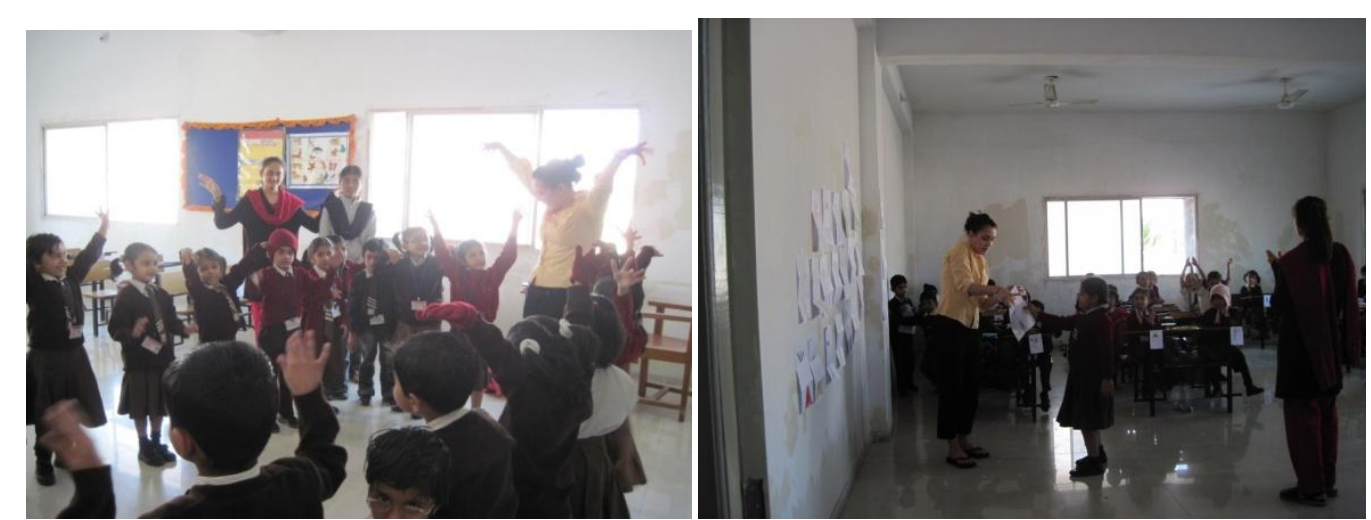

Billy B songs with teacher and B.Ed. student following MU student's directions - Tree Cycle PLT activity

This participation evolved into team teaching after a few days. The B.Ed. students also started to participate in this uncharted territory of manipulatives. The children were familiar with rote learning, but using manipulatives became exciting and a fun way to learn. They talked of all the activities conducted during the day to their families, who reported to the school principal their own enthusiasm for this new approach to learning. It was an interesting transition for all involved in teaching and learning through collaboration. Mutual cultural respect developed as team teaching built a foundation for this new concept of East and West joining hands in educating the young without boundaries. The Marymount students were clearly impressed by their Indian counter-parts' adaptability, and they also picked up some new ideas, such as the eleven times mental mathematics trick. (For example, $11 \mathrm{x} 13$ can easily be calculated by separating the 1 and the 3 and adding the two to make it four thus the answer being 143.) My American students found the Indian teachers and children exceptionally quick at mental math.

At one point, the host teachers took back the classrooms. Rushing around, they gathered materials and sought my input as they demonstrated a hands-on approach for the Marymount student observers. One of the activities conducted was based on transpiration and cohesion using flowers. The teacher had only blue ink to dye the water, and when I offered her the food coloring brought along from the United States, she was unsure if that would work. We tried all the colors in the food coloring pack along with the blue ink. The teacher was elated watching the dyes change the flowers from white to all colors of the food coloring. My students gained experiences that included working with diverse populations, higher education, and P-12 school faculty as stated in Standard 4 of the NCATE Professional Standards. This alternative methodology of teaching and learning and exchanging of ideas was well represented by a quote from Willa A. Foster, "Quality is never an accident; it is always the result of high intentions, sincere effort, intelligent direction, and skillful execution; it represents the wise choice of many alternatives."

At noon the bus returned the pre-service teachers to their hotel for an hour. This was the most precious moment for my students. They could have their Diet Coke and French fries. Fruits and uncooked vegetables were not recommended due to possible contamination, and eating meat was out of the question as the hotel and majority of the townspeople were vegetarian, following the Hindu religion. Also, Gujarat is a dry state, so students were unable to access any alcohol. Toward the end of the trip, the hotel ran out of Diet Coke; the manager reported it was the highest Coke consumption ever! 
Students returned to the school for intensive planning with the B.Ed. students and teachers from 1-2 p.m. daily. The beauty of this teaching and learning was evident through the exchange of ideas during this intensive training. Marymount University students explained and modified activities while the B.Ed. students and the teachers adapted them for their teaching environment. This broadened the horizon for my students as they learned alternative activities if they needed to modify their own. My students, for instance, conducted measuring activities with standard units whereas their Indian counterparts used the metric system-exemplifying how we approached math skills with two perspectives. Incorporating the lattice method in teaching multiplication skills, an alternative to long multiplication of numbers, interested everyone. This exchange of teaching and learning built a bond between Marymount students and both the host school teachers and B.Ed. students.

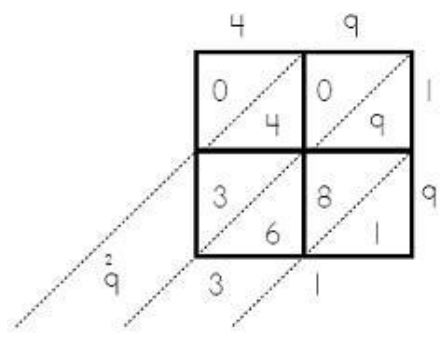

Lattice Multiplication method (Super Teacher worksheet, 2010)

This hour of cooperative teaching and learning was a huge undertaking. In a room packed with more than 60 participants, I not only translated to and from Gujarati but also taught the content knowledge. I relayed the methodology concept of a particular content area in science to all, with a few strategies on its application using a hands-on approach. The integrated teams of Marymount students, B.Ed. students, teachers, principal, and B.Ed. lecturers developed several different strategies of approaching the taught concept. The team had to implement some of these the following day within their own classrooms.

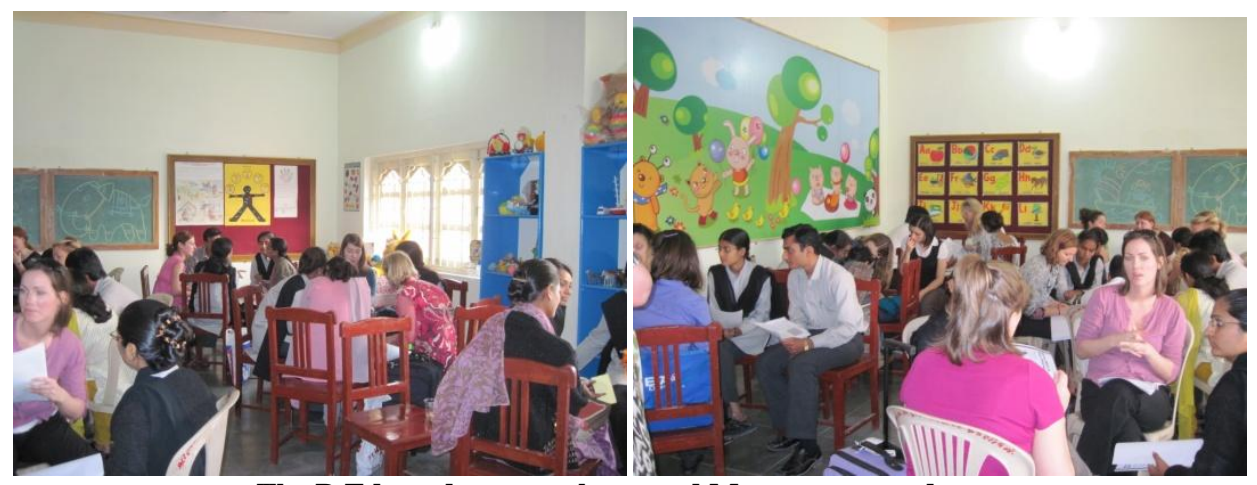

The B.Ed. students, teachers, and Marymount students: undergoing Projects WILD and Learning Tree training at Sandipani School.

At 2 p.m. the bus returned the students to the hotel—but only so another yellow school bus could pick them up and deliver them to a different school, in a less affluent area, where the morning program was repeated. This gave students an opportunity to modify and adjust activities that did not work well in the morning and gave them confidence as they improved their own teaching. Also run on charitable funds, this school, Sandipani Gurukul, caters to local children of low socioeconomic status. Absenteeism is rampant among both teachers and children. This school is newly built (about four years old) and the walls are all covered well with posters as seen in the above pictures.

The director of the school graciously arranged for the secondary students to recite Sanskrit verses for the Marymount students. Dressed in white loincloths and seated on the marble floor with their eyes shut, these students 
chanted the verses of praise or hymn called slokas (Devasthanam). The Marymount students were taken to the oldest Sanskrit literature library after the event, and each one was given a Bhagavata Gita, a Hindu scripture written both in Sanskrit and English. My students appreciated this, which increased their respect for the culture they were immersed in.

On our last day of teaching at Sandipani School, my students experienced the Bharat Natayam, an ancient Indian dance which is performed to this day. A Sandipani teacher not only demonstrated the dance but also taught a few steps to the Marymount students, who in return demonstrated a Western dance. This exchange of East and West needed no words, just an ear for music and an eye for motions of hands and feet.

On January 13 the time came to say our goodbyes to teachers and B.Ed. students of Dr. Virambhai Rajabhai Godhaniya College. The teachers set up a celebratory dinner and dance for Marymount University students. The entrance was beautifully designed with powdered paint décor, rangoli. We were showered with flowered petals as a gesture of special welcome. A group of female secondary students beautifully clad in red saris and head coverings danced a typical Gujarati garba. They were followed by a group of secondary boys, rather young men, who danced with swords and seemed to bounce off the floor. Finally came the big moment. The teachers invited Marymount students to join them in the dancing. It was a multicultural bond in the making (insert file seven). The teachers encompassed Marymount students in a circle. The teachers' flexibility and graceful motions humbled the Marymount students, fumbling the choreographing of their hands and feet simultaneously. Soon enough the East and the West danced the garba in a united line.

Marymount students also loved the typical Gujarati dinner, cooked on the premises, of kadhi (yogurt curry), khichadi (rice cooked with lentils), auro (eggplants mashed and cooked with garlic), rotli or chapatti (thin whole wheat bread) and rotla (millet flour bread). The meal was so well received that it became the top menu item back at the hotel for the next few days before departure.

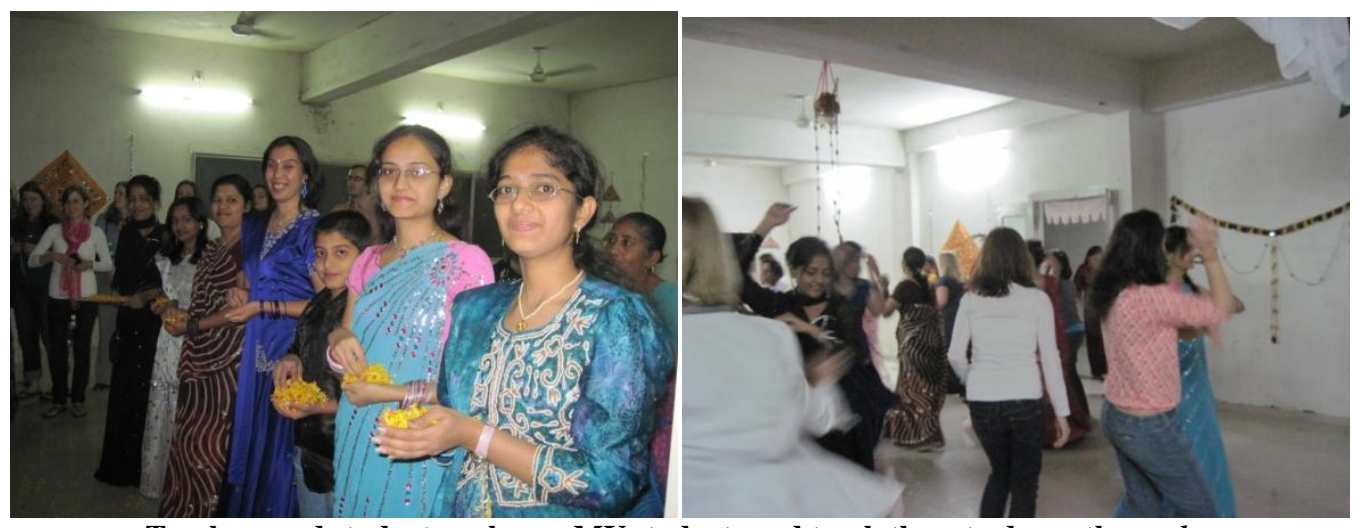

Teachers and students welcome MU students and teach them to dance the garba

January 14 was the kite flying festival, Makar Sankrati, marking the end of winter and welcoming spring. Marymount and B.Ed. students met on the school roof. The fun of who can fly a kite the highest and who can "cut," tangle, another's kite wore off as the cut kites dropped to the ground. Soon the head principal of the institute, Dr. Nagar, and the director of the B.Ed. program, Mr. Kakad, gave a farewell address. Quoting Rabindranath Tagore's poems electrifying the connection of teaching and learning, Dr. Nagar expressed gratitude for the cross-cultural exchanges that had occurred over the two weeks. The students were presented with gifts of Tagore's writings and an Indian souvenir. This was followed by a delicious luncheon, and when we returned to the hotel, the restaurant staff put up a show of kite flying and fireworks for the Marymount students. 


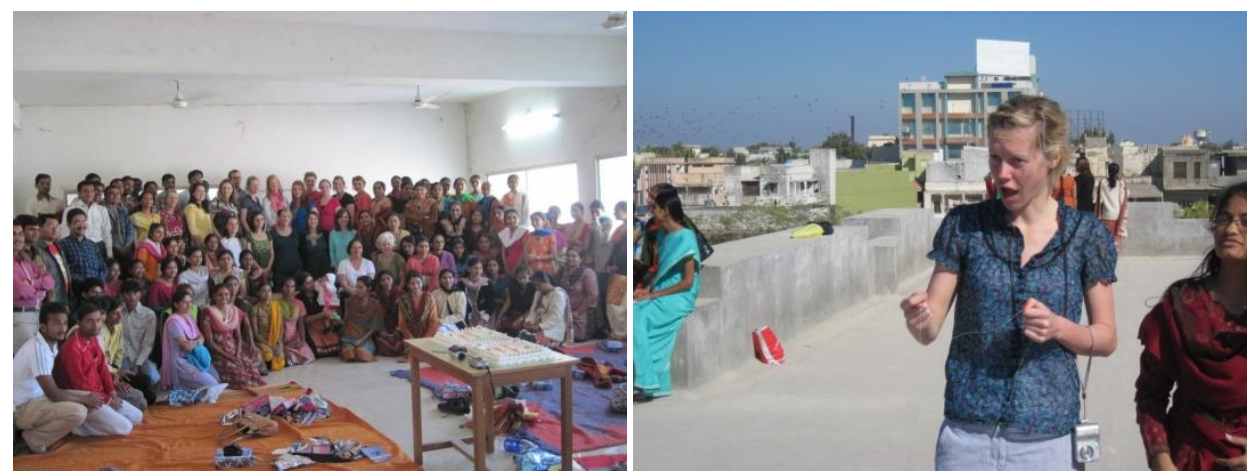

B.Ed. students' celebration with Marymount students and kite flying

January 15, the last half day before leaving Porbandar, Marymount students set up a systemic resource center for teachers and B.Ed. students to use in their absence. Donated by Marymount University and the students, the materials included hands-on math and science kits, Projects WILD and Learning Tree books, math and science textbooks, children's literature books, crayons, markers, and scissors. When the bus filled with Marymount students was about to depart on its final journey to the hotel, the children gathered in the courtyard shouting and waving their goodbyes. Then the students dashed off to their last minute shopping spree. Rickshaws (covered motorbike taxis) weaved in and out of the hotel picking up the students and dropping them off with their bags. The B.Ed. students kindly accompanied them to help with bargaining and checking that monetary exchanges were all made with clear conscience by the shop keepers. Then the Marymount students were off for a few final days of sightseeing: Gandhi's birthplace in Porbandar, the Taj Mahal in Agra, and Raj Ghat (Gandhi Memorial) in Delhi.

\section{BENEFITS}

This program not only created a richer learning environment for the Pre-K-7 students in India but also provided opportunities for the B.Ed. candidates and participating faculty to enhance their professional skills while serving as a model for other Indian colleges and universities as they attempt to prepare teachers for successful careers in a global learning society. The greatest benefit to Marymount University is establishing a foundation for future study abroad programs in India and elsewhere. Also, the students' experiences in Porbandar will be an asset in any school in the United States with a diverse population and provide them with better job prospects in the future.

\section{EVALUATION PLAN}

In my closing discussions with the principal and a member of the governing board of the first school, it became evident that this program should be continued, with a follow-up visit in July 2010 to review progress and plan future program development. At the meeting the governing board member also expressed the need for technology training. The focus will be on classroom observations, assisting in the use of resources, and further methodology training to expand on the program started in January. My future visits will include teaching new strategies and their applications, a review of the use of the resources left behind for implementation in the classrooms, and a reinforcement of the methodologies introduced in the January 2010 session. The visit in July 2010 will play an integral part in the follow-up of all study abroad programs to come.

I will measure the success of the project through observation, participation, interviews, and reported results from the school. I will not be directly involved in obtaining the test results but will rely on the Jayshreeben Virambhai Godhaniya English Medium School to perform the assessments, with permission requested from the main principal of the host school to interview children, teachers, and B.Ed. students. Protocols for these interviews will be coordinated among the three participating institutions. The school administers tests to children twice a year. Results are used to determine academic standing only. Thus, interviews would be valuable tools for understanding whether the program has promoted the students' abilities to grasp conceptual skills through a hands-on approach. Along with the interview process, I will carry out observations in the classrooms to determine the use and value of materials as well as the children's understanding of the concepts being taught. I will be participating in both the 
teaching and learning process, and I will conduct a feedback session as to the best practices demonstrated so far and what can be done to improve and advance the program.

The B.Ed. students will be valuable assets in determining the success of the program. Their input through interviews and observations will be as important as interviewing and observing the teachers. Even though the B.Ed. students do not teach in the primary school setting under their normal program schedule, they were participants at the time of the study abroad program in January 2010. Their initial training is based on a traditional teaching style, so it will be interesting to see what steps, if any, they have taken to adopt a hands-on teaching approach. Also, I will spend time assisting the teachers and B.Ed. students in using technology and understanding the basics of using emails, researching, and planning lessons in math and science to design both traditional and performance-based assessments. They will write behavioral objectives, include age appropriate activities, use hands-on activities in a discovery approach, and adapt lessons for special needs populations, gender equity, LEP/ESL/ Multicultural, and at risk children with physical/mental disabilities. They will build on their portfolio for future professional growth and development by saving frameworks for planning and instruction.

\section{FUTURE POSSIBILITIES}

I anticipate expanding and strengthening the program by inviting other Indian schools in and around Porbandar to join in this collaboration process with the pre-service teachers, teachers and B.Ed. students. My long term goal is to build on a teacher education conference on regular basis for the Indian counterparts to benefit from teaching and learning in partnership with Marymount University. The model created by this program can be replicated by other colleges and universities to advance teacher education in a global society.

\section{AUTHOR INFORMATION}

Usha Rajdev is an Associate Professor in education at Marymount University in Arlington, Virginia. Her research foci include Ethics: in the classroom management and children's errors and misconceptions in mathematics. She teaches math and science methodology to both undergraduate and graduate students through a constructivist approach. She is also a Counselor for Kappa Delta Pi, a faculty advisor for National Science Teachers Association Student Chapter, and an assessment coordinator in Marymount University's education department. She has conducted two study abroad service learning projects in India.

\section{REFERENCES}

1. Devasthanam: A hindu resource where faith and scholarship meet. [cited March/12 2010]. Available from http://www.sanskrit.org/.

2. Education Department of Gujarat. [cited March/10 2010]. Available from http://gujarateducation.gov.in/education/. http://gcert.gujarat.gov.in/gcert/showcase/project-based-learning.htm

3. Gardner, Howard. 1983. Frames of Mind: The theory of multiple intelligences. New York: Basic Books.

4. Greene, Ed. Harvard Family Research Project. How can we prepare teachers to work with culturally diverse students and their families? What skills should educators develop to do this successfully? [cited March/12 2010]. Available from http://www.hfrp.org/family-involvement/fine-family-involvementnetwork-of-educators/member-insights/how-can-we-prepare-teachers-to-work-with-culturally-diversestudents-and-their-families-what-skills-should-educators-develop-to-do-this-successfully.

5. Hughes, Sherick. Harvard Family Research Project. How can we prepare teachers to work with culturally diverse students and their families? What skills should educators develop to do this successfully? [cited March/12 2010]. Available from http://www.hfrp.org/family-involvement/fine-family-involvementnetwork-of-educators/member-insights/how-can-we-prepare-teachers-to-work-with-culturally-diversestudents-and-their-families-what-skills-should-educators-develop-to-do-this-successfully.

6. National Council for Accreditation of Teacher Education. [cited March/8 2010]. Available from http://www.ncate.org/public/standards.asp, http://www.ncate.org/public/NCATERedesign.asp\#top.

7. Super Teacher Worksheets (free, printable math and ELA worksheets for teachers and home school families). [cited March/12 2010]. Available from http://www.superteacherworksheets.com/index.html.

8. Dr. Virambhai Rajabhai Godhaniya College. Available from http://drvrginstitute.org/institute.php. 
NOTES 